\title{
SYNTHESIS AND CHARACTERIZATION OF RESOL TYPE PHENOL-FORMALDEHYDE RESIN IMPROVED $\mathrm{BYSIO}_{2}-\mathrm{NP}$
}

\author{
GÜnAY ÖZbay \\ Aksaray University \\ TuRKEY \\ Erkan Sami KoKten \\ Karabuk University \\ TurKey \\ Ayhan Ozcifci \\ Aksaray University \\ TURKeY \\ (Received February 2020)
}

\begin{abstract}
In this work, resol type phenol-formaldehyde (RPF) resin was modified with silicon dioxide nanoparticles $\left(\mathrm{SiO}_{2}-\mathrm{Np}\right)$. $\mathrm{SiO}_{2}-\mathrm{Np}$ was added at varying ratios from 1 to $4 \mathrm{wt} . \%$ to improve the bonding performance of the RPF resins. The physical characteristics of the nano-modified RPF (nano-RPF) resins were examined. The effects of modification were studied by Fourier transform infrared spectroscopy (FT-IR) and thermogravimetric analysis (TGA). The results of FT-IR revealed that the nano-RPF resins were successfully produced by phenol, formaldehyde, and $\mathrm{SiO}_{2}-\mathrm{Np}$. The nano-RPF resins demonstrated high thermal stability at temperatures above $500^{\circ} \mathrm{C}$. The adhesive performance of the nano-RPF resins was investigated under dry and wet conditions. The nano-RPF resins indicated better adhesive performance than unmodified RPF resin. The RPF resin could be improved by $\mathrm{SiO}_{2}-\mathrm{Np}$.
\end{abstract}

KEYWORDS: Adhesive performance, phenol-formaldehyde, silica nanoparticles, thermal stability.

\section{INTRODUCTION}

Phenol-formaldehyde pre-polymer $(\mathrm{PF})$ resins are the major types of thermosetting polymers, which are widely used as an adhesive by the wood industry is because of its number of 
advantages, such as high strength and extremely resistant to moisture of the cured resin (Kariž et al. 2009). PF resins are categorized into two main groups: resols or novolacs depending on the type of catalyst that are used in the production process of the resin. Resol type phenolformaldehyde resins (RPF) are obtained by the polycondensation reaction of formaldehyde and phenol in a high-alkaline environment. The RPF resins have good thermal, chemical and mechanical properties (Viswanathan and Richardson 1985, Haupt and Sellers 1994, Schmidt 2005, Zhang and Sigman 2007, Riedlinger and Frazier 2008, Moubarik et al. 2009, Roslan et al. 2014, Kurt and Cavus 2011).

There are many studies on PF resin modification by different types of chemicals including boron carbide, boric acid, propylene carbonate, sodium carbonate, and potassium carbonate in order to improve adhesive performance (Gao et al. 1999, Park et al. 1999, Wang et al. 2010). Also, many different types of nano-chemicals such as nano- $\mathrm{TiO}_{2}$, nano- $\mathrm{SiO}_{2}$, nano- $\mathrm{Fe}_{2} \mathrm{O}_{3}$, nano$\mathrm{Al}_{2} \mathrm{O}_{3}$, and nano- $\mathrm{CaCO}_{3}$ particles were examined in order to enhance the thermal stability and/ or the bond strength of thermosetting adhesives. It was pointed out that the use of nano-chemical could improve the adhesive properties (Cao et al. 2002, Bauer et al. 2006, Li et al. 2007, Shi et al. 2008, Wang et al. 2011). However, there is still a need for experimental studies involving the usage of the nano-chemicals in the polycondensation reaction of the RPF resins production and their applications in the wood products industry.

The purpose of this study is to use silicon dioxide nanoparticles $\left(\mathrm{SiO}_{2}-\mathrm{Np}\right)$ in the RPF resin synthesis to enhance the adhesive performance of the nano-RPF resins. For this purpose, the effect of $\mathrm{SiO}_{2}-\mathrm{Np}$ additives and loading ratio on the chemical and thermal characteristics of the resins were studied by FT-IR and TGA analysis respectively. Then, the bonding performance of laminated wood bonded with the nano-RPF resins was experimentally investigated under indoor/ outdoor exposures.

\section{MATERIALS AND METHODS}

\section{Materials}

Phenol (liquid) and formaldehyde (at a concentration of 37\%) were commercial products supplied by GENTAŞ, Turkey. Nano-SiO 2 with the particle size of about 20-30 nm and the density of $0.1-0.15 \mathrm{~g} \cdot \mathrm{cm}^{-3}$, was supplied by Sigma Aldrich. The beech (Fagus orientalis Lipsky) wood planks with a density of $0.670 \mathrm{~g} \cdot \mathrm{cm}^{-3}$ were used to evaluate the adhesive performance.

\section{Synthesis of the nano-PF resins}

The RPF resin syntheses were conducted in a laboratory glass reactor equipped with a condenser, a magnetic stirrer, and a thermometer. The reference resin was based on an unmodified RPF resin (Laboratory made RPF resin). The RPF resin synthesis procedure was as follows: The mixture of phenol and formaldehyde was fed into the reactor and, when the temperature of $60^{\circ} \mathrm{C}$ was reached, the catalyst, a $2 / 3$ of total $\mathrm{NaOH}$ solution (50 wt.\%), was added. The mixture was heated to $90^{\circ} \mathrm{C}$ and, it was followed that the resulting mixtures were heated at $90^{\circ} \mathrm{C}$ under stirring for $60 \mathrm{~min}$. Then, it was cooled down to a temperature of $60^{\circ} \mathrm{C}$. The second part of $\mathrm{NaOH}$ ( 50 wt.\%) (1/3 of total $\mathrm{NaOH}$ weight solution) was added to adjust the $\mathrm{pH}$ to $11.0-12.0$ into the reactor at this temperature. At end of the reaction, the mixture was allowed to cool to room temperature. The route for the synthesis of the nano-RPF resins was basically the same as RPF synthesis method. Before the synthesis, various amount of nano- $\mathrm{SiO}_{2}$ was mixed uniformly with phenol and formaldehyde at room temperature. Loading of the $\mathrm{SiO}_{2}-$ $\mathrm{Np}$ in the formulations was variable; $1 \%, 2 \%$, and $4 \%$. 


\section{Characterization}

Resol type phenolic resins are generally characterized for final viscosity, $\mathrm{pH}$ value, gel time, and solid content. A TES-1380 digital $\mathrm{pH}$ meter was employed for $\mathrm{pH}$ measurements. Viscosity measurements were carried out at a temperature of $25^{\circ} \mathrm{C}$ by using a Brookfield viscometer (model: Dv-IPrime). The resin solids content was measured in accordance with ASTM D 3529 (ASTM D3529M-97 2008).

The gel time of the resin was measured at $100^{\circ} \mathrm{C}$. The test tube filled with $5 \mathrm{~g}$ of prepared the resin was immersed into boiling water and then, constant stirring was applied throughout the test. The elapsed time until the point when no further stirring was possible was defined as the gel time for the sample. The gel time of the resin was determined according to a procedure reported by Haupt and Sellers (1994). Infrared spectra were recorded an Alpha Fourier transform infrared spectrometer. IR spectra were obtained using a frequency range of $4000-400 \mathrm{~cm}^{-1}$ with a resolution of $4 \mathrm{~cm}^{-1}$ and 40 scans. Thermogravimetric analysis (TGA) was carried out on a HITACHI STA 7300 thermogravimetric analyzer at $5{ }^{\circ} \mathrm{C} / \mathrm{min}$ under air atmosphere under the nitrogen atmosphere.

\section{Preparation of wood samples and testing}

The selected wood lamellas were obtained from beech wood planks with the dimensions of $5 \times 50 \times 500 \mathrm{~mm}$ in the radial, tangential and longitudinal directions, respectively. The lamellas were acclimatized at $20 \pm 2^{\circ} \mathrm{C}$ and $65 \pm 3 \%$ relative humidity in an acclimatization room. The resin was uniformly applied at the amount of about $180 \mathrm{~g} \cdot \mathrm{m}^{-2}$ manually by hand brush. Resin was applied on one lamella only. Two wood lamellas bonded with the RFP resin has assembled and hot-pressed under $1.6 \mathrm{MPa}$ pressure at $130^{\circ} \mathrm{C}$, for $10 \mathrm{~min}$. The samples were acclimatized in a chamber having $65 \%$ relative humidity and temperature of $20^{\circ} \mathrm{C}$ and then cut into samples with the dimensions of $10 \times 20 \times 150 \mathrm{~mm}$ after the corresponding pre-treatment according to EN 12765 (2002). In bonding tests, 24 samples were evaluated for each group. During the test, the loading was applied centrally and in the plane of the bond. The loading was continued until a break at $2 \mathrm{~mm} \cdot \mathrm{min}^{-1}$. The bonding test was performed on a Zwick/Roell Z50 universal testing machine according to BS EN 205 (2003) standard. The following equation was used in order to calculate the tensile shear strength:

$$
\sigma_{y}=F_{\max } / A=F_{\max } / l_{2} \cdot b
$$

where: $\sigma_{y}$ is the tensile shear strength $\left(\mathrm{N} \cdot \mathrm{mm}^{-2}\right), F_{\max }$ is the applied maximum load $(\mathrm{N}), \mathrm{A}$ is the bonding surface of sample $\left(\mathrm{mm}^{2}\right), l_{2}$ is the length of the bonded surface $(\mathrm{mm})$, and $b$ is the width of the bonded surface $(\mathrm{mm})$.

\section{RESULTS AND DISCUSSION}

\section{Physical characterization}

The physical characteristics of the nano-RPF resins are given in Tab. 1. In a comparison of nano-RPF resins with reference resin, the final $\mathrm{pH}$ value of the nano-PFR slightly decreases with increasing nano- $\mathrm{SiO}_{2}$ content. As the amount of the nano- $\mathrm{SiO}_{2}$ was increased from $1 \mathrm{wt} . \%$ to $4 \mathrm{wt} . \%$, the $\mathrm{pH}$ value of the nano-RPF was decreased from 11.84 to 11.62 . The decrement of the $\mathrm{pH}$ values could be attributed to the low $\mathrm{pH}$ value of the nano- $\mathrm{SiO}_{2}$, which is below 3 . The viscosity of nano- $\mathrm{RPF}$ resins was affected by $\mathrm{SiO}_{2}-\mathrm{Np}$ content. As the $\mathrm{SiO}_{2}-\mathrm{Np}$ content 
increased, the viscosity values of nano-RPF resins also increased. The lowest viscosity with a value of $285 \mathrm{cPs}$ was measured for the reference RPF resin, while the highest viscosity with a value of 315 cPs was determined for the 4 wt.\% $\mathrm{SiO}_{2}-\mathrm{Np}$ modified RPF resin. It can be explained that the high molecular weight of the nano- $\mathrm{SiO}_{2}$ caused an increase in the viscosity of the resin. 4 wt.\% $\mathrm{SiO}_{2}-\mathrm{Np}$ modified $\mathrm{RPF}$ resin had the longest gel time when compared to the reference RPF resin. The solids contents of all the resins including reference RPF and nano-RPF resins were determined to be above $40 \mathrm{wt} . \%$. The $\mathrm{SiO}_{2}-\mathrm{Np}$ additive has slightly increased the solids content of the nano-RPF resins. The lowest solid content with a value of $42.84 \mathrm{wt} . \%$ was determined for the reference RPF resin, while the highest solid content with a value of $43.51 \mathrm{wt} . \%$ was measured for the $4 \mathrm{wt} . \% \mathrm{SiO}_{2}-\mathrm{Np}$ modified RPF resin (Tab. 1). As reported in the literature, the resin solid content is one of the most important characteristics of phenolic resin. The low solid content adhesive could be ejected out more water during the hot-press processing (Lin et al. 2014).

Tab. 1: Physical characteristics of the nano-PF resins.

\begin{tabular}{|c|c|c|c|c|c|}
\hline Resin type & $\begin{array}{c}\mathrm{SiO}_{2}-\mathrm{Np}_{\mathrm{p}} \\
(\mathrm{wt} . \%)\end{array}$ & $\begin{array}{c}\mathrm{pH} \\
\left(20^{\circ} \mathrm{C}\right)\end{array}$ & $\begin{array}{c}\text { Viscosity } \\
\left(25^{\circ} \mathrm{C}, \mathrm{cPs}\right)\end{array}$ & $\begin{array}{c}\text { Solid content } \\
(\%)\end{array}$ & $\begin{array}{c}\text { Gel time } \\
\left(100^{\circ} \mathrm{C}\right)(\mathrm{s})\end{array}$ \\
\hline $\mathrm{Reference} \mathrm{RPF}^{2}$ & 0 & 11.98 & 285 & 42.84 & 170 \\
\hline $1 \% \mathrm{SiO}_{2}-\mathrm{Np} / \mathrm{RPF}$ & 1 & 11.84 & 301 & 43.17 & 173 \\
\hline $2 \% \mathrm{SiO}_{2}-\mathrm{Np} / \mathrm{RPF}$ & 2 & 11.70 & 309 & 43.24 & 176 \\
\hline $4 \% \mathrm{SiO}_{2}-\mathrm{Np} / \mathrm{RPF}$ & 4 & 11.62 & 315 & 43.51 & 188 \\
\hline
\end{tabular}

\section{Thermogravimetric analysis}

The TGA analysis of the nano-RPF resins was evaluated in a large range of temperatures and it was considered as a measure of the thermal stability. Fig. 1 displays the TGA thermograms of the reference RPF resin and nano-RPF resins. It can be seen that the variations in the thermal stability of the $\mathrm{SiO}_{2}-\mathrm{Np}$ modified $\mathrm{RPF}$ resin depend upon the temperatures and $\mathrm{SiO}_{2}-\mathrm{Np}$ contents. The thermal degradation of these resins can be divided into three regions: $30^{\circ} \mathrm{C}$ to $120^{\circ} \mathrm{C}, 120^{\circ} \mathrm{C}$ to $300^{\circ} \mathrm{C}$, and $300^{\circ} \mathrm{C}$ to $600^{\circ} \mathrm{C}$. The first region occurred between $30^{\circ} \mathrm{C}$ and $120^{\circ} \mathrm{C}$. This region is probably connected to the removal of the hydroxyl groups. Second region, between $120^{\circ} \mathrm{C}$ and $300^{\circ} \mathrm{C}$, could be related to the terminal weak or strong $\mathrm{OH}$ groups. Nano-RPF resins were thermally stable up to $300^{\circ} \mathrm{C}$. This thermal stabilization may be explained by new structures, which can be formed during resin synthesis. They are thermally stable until the whole polymer structure collapses (Lin et al. 2006). The weight loss occurs at temperatures between $300^{\circ} \mathrm{C}$ and $600^{\circ} \mathrm{C}$ and is caused by oxidative resin degradation. The thermal degradation of the reference RPF resin was higher than the nano-RPF resins. At temperatures below $300^{\circ} \mathrm{C}$, nano-RPF resins showed higher thermal stability than reference RPF resin. RPF resin with $2 \%$ and $4 \% \mathrm{SiO}_{2}-\mathrm{Np}$ had higher thermal stability than $\mathrm{RPF}$ resin with $1 \% \mathrm{SiO}_{2}-\mathrm{Np}$ content. At temperatures higher than $300^{\circ} \mathrm{C}$, the thermal stability of $\mathrm{SiO}_{2}-\mathrm{Np}$ modified $\mathrm{RPF}$ resins was higher than that of the reference RPF resin. It can be said that the thermal stability of the RPF resin could be improved by $\mathrm{SiO}_{2}-\mathrm{Np}$. The similar findings, on the thermal stability of phenolic resins, were also reported by Burns and Orrell (1967), Chen et al. (2008), Wang et al. (2011), Bian et al. (2015) as well as Kokten et al. (2020). 


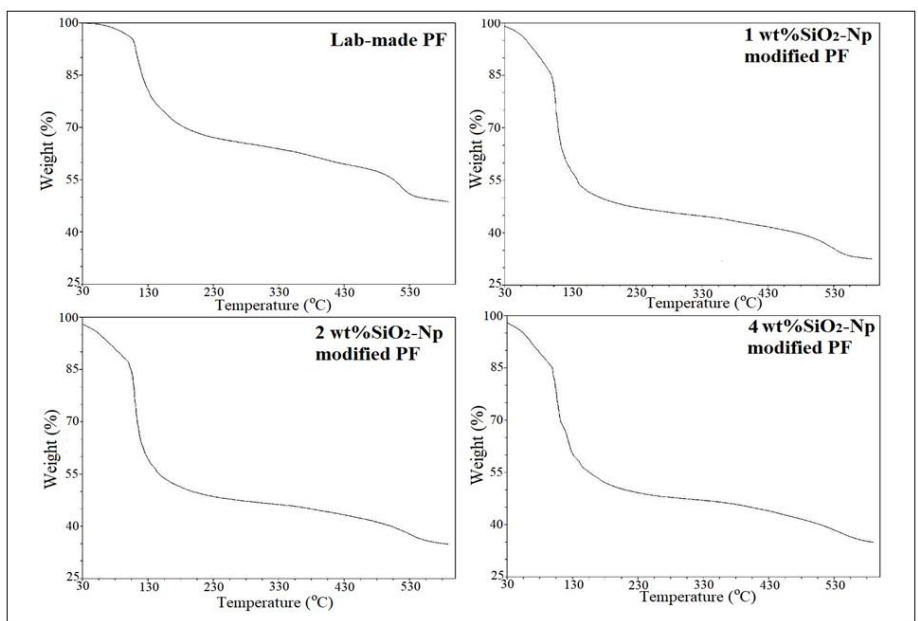

Fig. 1: TGA thermograms of the $\mathrm{RPF}$ resins modified by $\mathrm{SiO}_{2}-\mathrm{Np}$.

\section{FT-IR spectroscopy}

FT-IR analysis was used to confirm the modification of the RPF and determine the effect of $\mathrm{SiO}_{2}-\mathrm{Np}$ on the chemical structure of the RPF resin. The results are shown in Fig. 2. The intense $\mathrm{OH}$ stretching band at $3450 \mathrm{~cm}^{-1}$ indicated that there are two different types of -OH group: phenolic and alcoholic. The peak shown in the range of $2900-2950 \mathrm{~cm}^{-1}$ indicated the symmetrical C-H stretch of $\mathrm{CH} 2$. The peaks at around 1700 and $1750 \mathrm{~cm}^{-1}$ assigned to the $\mathrm{C}=\mathrm{C}$ stretching vibrations aromatic ring vibrations group, and also the peak at $1220-1250 \mathrm{~cm}^{-1}$ represented the $\mathrm{C}-\mathrm{O}$ stretching in aromatic ring for all $\mathrm{RPF}$ resin. The stretching of $\mathrm{C}-\mathrm{O}-\mathrm{C}$ was found in all RPF resin at $850 \mathrm{~cm}^{-1}$. The characteristic peaks of phenolic compounds were observed at about 1600,1500,1450,1220, and $850 \mathrm{~cm}^{-1}$, as reported in previous FT-IR studies on the PF resin (Liu et al. 2002, Chen et al. 2008, Wang et al. 2009, Zhao et al. 2013, Bobrowski and Grabowska 2015, Cui et al. 2017). New absorptions at $1650 \mathrm{~cm}^{-1}$ and $1680 \mathrm{~cm}^{-1}$ appeared to compare with the reference RPF resin, the absorptions of the RPF resin containing 4 wt.\% $\mathrm{SiO}_{2}-\mathrm{Np}$ at $1070-1090 \mathrm{~cm}^{-1}$, representing the dissymmetry flexible vibration of linear $\mathrm{Si}-\mathrm{O}-\mathrm{Si}$, is more obviously compared to that of the RPF resin containing $1 \mathrm{wt} . \% \mathrm{SiO}_{2}-\mathrm{Np}$. The FT-IR results showed that the structures of nano-RPF and the reference RPF resins were similar. This similarity confirmed that nano-RPF resins were successfully synthesized with the $\mathrm{SiO}_{2}-\mathrm{Np}$, phenol, and formaldehyde under the alkali environment.

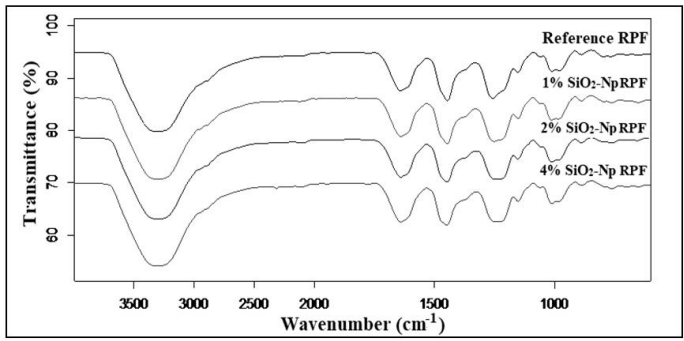

Fig. 2: FT-IR spectra of the nano-RPF resins. 


\section{Adhesive performance of the nano-RPF resins}

The bond strength values of the specimens are presented in Tab. 2. The highest bond strength with a value of $11.87 \mathrm{~N} \cdot \mathrm{mm}^{-2}$ was found for the $2 \mathrm{wt} . \% \mathrm{SiO}_{2}-\mathrm{Np}-\mathrm{RPF}$ specimens, followed by 1 wt.\% $\mathrm{SiO}_{2}-\mathrm{Np}-\mathrm{RPF}$ specimens $\left(10.92 \mathrm{~N} \cdot \mathrm{mm}^{-2}\right)$, reference $\mathrm{RPF}$ specimens $\left(10.54 \mathrm{~N} \cdot \mathrm{mm}^{-2}\right)$, and $4 \mathrm{wt} . \% \mathrm{SiO}_{2}-\mathrm{Np}-\mathrm{RPF}$ specimens $\left(9.76 \mathrm{~N} \cdot \mathrm{mm}^{-2}\right)$ under dry conditions (pretreatment 1). The specimens bonded with RPF resins modified by the $\mathrm{SiO}_{2}-\mathrm{Np}$ with 1 wt.\% and $2 \mathrm{wt} . \%$ exceeded standard requirements for the durability of class $\mathrm{C} 1\left(10 \mathrm{~N} \cdot \mathrm{mm}^{-2}\right)$ as defined by EN 12765 (EN 12765 2002). The bond strength values of the resins showed a significant drop under wet conditions, especially pre-treatments 3. The RPF resin containing 2 wt. $\% \mathrm{SiO}_{2}-\mathrm{Np}$ had the highest strength, while the RPF resin containing 4 wt.\% $\mathrm{SiO}_{2}-\mathrm{Np}$ reached lower bond strength values after the pre-treatment 2 and pre-treatment 3 . However, for the pre-treatment 2 and pre-treatment 3, the RPF resins containing up to 4 wt.\% $\mathrm{SiO}_{2}-\mathrm{Np}$ satisfy the requirements for durability classes $\mathrm{C} 2\left(7 \mathrm{~N} \cdot \mathrm{mm}^{-2}\right)$ and $\mathrm{C} 3\left(4 \mathrm{~N} \cdot \mathrm{mm}^{-2}\right)$, respectively (Tab. 2). The bond strength test results demonstrated that the bonding performance of the RPF resin could be achieved with $\mathrm{SiO}_{2}-\mathrm{Np}$ addition up to $2 \mathrm{wt} . \%$ in dry or wet conditions. Many studies stated that silica nanoparticles showed high strength, thermal stability, and chemical stability for polymer materials (Zhou et al. 2003, Sun et al. 2006, Yang et al. 2006, Qin et al. 2017, Zhang et al. 2018).

Tab. 2: The bond strength values of the $\mathrm{SiO}_{2}-\mathrm{Np}$ modified $\mathrm{RPF}$ resins.

\begin{tabular}{|l|c|c|c|}
\hline \multicolumn{1}{|c|}{ Type of PF resin } & $\begin{array}{c}\text { Pre-treatment 1 } \\
(\mathrm{C} 1>10)^{\mathrm{a}}\end{array}$ & $\begin{array}{c}\text { Pre-treatment 2 } \\
(\mathrm{C} 2>7)^{\mathrm{a}}\end{array}$ & $\begin{array}{c}\text { Pre-treatment 3 } \\
(\mathrm{C} 3>4)^{\mathrm{a}}\end{array}$ \\
\hline $\mathrm{Reference} \mathrm{RPF}$ & $10.54(0.26) \mathrm{b}$ & $7.38(0.21)$ & $5.69(0.39)$ \\
\hline $1 \% \mathrm{SiO}_{2}-\mathrm{Np} / \mathrm{RPF}$ & $10.92(0.32)$ & $7.44(0.34)$ & $6.03(0.43)$ \\
\hline $2 \% \mathrm{SiO}_{2}-\mathrm{Np} / \mathrm{RPF}$ & $11.87(0.48)$ & $7.59(0.31)$ & $6.14(0.35)$ \\
\hline $4 \% \mathrm{SiO}_{2}-\mathrm{Np} / \mathrm{RPF}$ & $9.76(0.32)$ & $6.58(0.45)$ & $5.27(0.41)$ \\
\hline
\end{tabular}

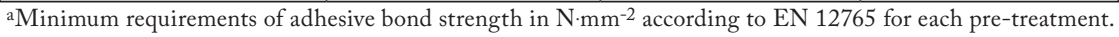
bThe values in the parentheses are standard deviations.

\section{CONCLUSIONS}

The purpose of this study is to show usability of silicon dioxide nanoparticles $\left(\mathrm{SiO}_{2}-\mathrm{Np}\right)$ in the RPF resin synthesis to enhance the adhesive performance of the nano-RPF resins. The effect of $\mathrm{SiO}_{2}-\mathrm{Np}$ contains on the physical, chemical, and thermal characteristics of the resins were examined. The following conclusions can be outlined:

- The physical characteristics such as $\mathrm{pH}$, viscosity, solid content and gel time of the nano$\mathrm{RPF}$ resin were affected by $\mathrm{SiO}_{2}-\mathrm{Np}$ content.

- The RPF resins modified by $\mathrm{SiO}_{2}-\mathrm{Np}$ showed higher thermal stability than the reference RPF resin. The RPF resin with $2 \%$ and $4 \% \mathrm{SiO}_{2}-\mathrm{Np}$ had higher thermal stability than RPF resin with $1 \% \mathrm{SiO}_{2}-\mathrm{Np}$ content. The thermal stability of the $\mathrm{RPF}$ resin could be improved by $\mathrm{SiO}_{2}-\mathrm{Np}$.

- The results of the FT-IR spectrum showed that the nano-RPF had a similar FT-IR spectrum to the reference RPF resin. The molecular structure relationship demonstrated that nano-RPF resins were successfully synthesized with the $\mathrm{SiO}_{2}-\mathrm{Np}$, phenol, and formaldehyde under the alkali environment.

- The adhesive performance test results revealed that the bond strength of the RPF resin could be improved with $\mathrm{SiO}_{2}-\mathrm{Np}$ addition up to $2 \mathrm{wt} . \%$. Nano-based resins can be used in the production of wood adhesives. 


\section{ACKNOWLEDGMENTS}

The authors would like to thanks the Aksaray University, Research Foundation (No. 2018008) for the financial support that made this work possible. Thanks also to Research Assistant İlknur ULUDAG for the proofreading.

\section{REFERENCES}

1. ASTM D3529M-97, 2008: Standard test method for matrix solids content and matrix content of composite prepreg.

2. Bauer, F., Decker, U., Ernst, H., Findeisen, M., Langguth, H., Mehnert, R., Sauerland, V., Hinterwaldner, R., 2006: Functionalized inorganic/organic nanocomposites as new basic raw materials for adhesives and sealants. Part 2. International Journal of Adhesion and Adhesives 26(7): 567-570.

3. Bian, C., Wang, Y., Wang, S., Zhong, Y., Liu, Y., Jing, X., 2015: Influence of borate structure on the thermal stability of boron-containing phenolic resins: A DFT study. Polymer Degradation and Stability 119: 190-197.

4. Bobrowski, A., Grabowska, B., 2015: FTIR method in studies of the resol type phenol resin structure in the air atmosphere in some time intervals. Metallurgy and Foundry Engineering 41(3): 107.

5. BSEN 205,2003: Adhesives. Wood adhesives for non-structural applications. Determination of tensile shear strength of lap joints.

6. Burns, R., Orrell, E.W., 1967: A thermal analytical study of phenol formaldehyde resins. Journal of Materials Science 2(1): 72-77.

7. Cao, Y.M., Sun, J., Yu, D.H., 2002: Preparation and properties of nano- $\mathrm{Al}_{2} \mathrm{O}_{3}$ particles/ polyester/epoxy resin ternary composites. Journal of Applied Polymer Science 83(1): 70-77.

8. Chen, Y., Chen, Z., Xiao, S., Liu, H., 2008: A novel thermal degradation mechanism of phenol-formaldehyde type resins. Thermochimica Acta 476(1): 39-43.

9. Cui, Y., Hou, X., Wang, W., Chang, J., 2017: Synthesis and characterization of bio-oil phenol formaldehyde resin used to fabricate phenolic based materials. Materials (Basel), 10(6): 668.

10. EN 12765, 2002: Classification of thermosetting wood adhesives for non-structural applications.

11. Gao, J., Liu, Y., Yang, L., 1999: Thermal stability of boron-containing phenol formaldehyde resin. Polymer Degradation and Stability 63(1): 19-22.

12. Haupt, R.A., Sellers, T.J., 1994: Characterizations of phenol-formaldehyde resol resins. Industrial \& Engineering Chemistry Research 33(3): 693-697.

13. Kariž, M., Jošt, M., Sernek, M., 2009: Curing of phenol-formaldehyde adhesive in boards of different thicknesses. Wood Research 54(2): 41-48.

14. Kokten, E.S., Özbay, G., Ayrilmis, N., 2020: Synthesis of biobased phenolic resins using catalytic pyrolysis oil and its effect on oriented strand board performance. The Journal of Adhesion 96(5): 475-489.

15. Kurt, R., Cavus, V., 2011: Manufacturing of parallel strand lumber (PSL) from rotary peeled hybrid poplar I-214 veneers with phenol formaldehyde and urea formaldehyde adhesives. Wood Research 56(1): 137-144. 
16. Li, H., Zhang, Z., Ma, X., Hu, M., Wang, X., Fan, P., 2007: Synthesis and characterization of epoxy resin modified with nano- $\mathrm{SiO}_{2}$ and $\gamma$-glycidoxypropyltrimethoxy silane. Surface and Coatings Technology 201(9-11): 5269-5272.

17. Lin, R., Fang, L., Li, X., Xi, Y., Zhang, S., Sun, P., 2006: Study on phenolic resins modified by copper nanoparticles. Polymer Journal 38(2): 178.

18. Lin, R., Sun, J., Yue, C., Wang, X., Tu, D., Gao, Z., 2014: Study on preparation and properties of phenol-formaldehyde-chinese fir liquefaction copolymer resin. Maderas Ciencia y Tecnologia 16(2): 159-174.

19. Liu, Y., Gao, J., Zhang, R., 2002: Thermal properties and stability of boron-containing phenol-formaldehyde resin formed from paraformaldehyde. Polymer Degradation and Stability 77(3): 495-501.

20. Moubarik, A., Pizzi, A., Allal, A., Charrier, F., Charrier, B., 2009: Cornstarch and tannin in phenol-formaldehyde resins for plywood production. Industrial Crops and Products 30(2): 188-193.

21. Park, B.D., Ried1, B., Hsu, E.W., Shields, J., 1999: Differential scanning calorimetry of phenol-formaldehyde resins cure-accelerated by carbonates. Polymer 40(7): 1689-1699.

22. Qin, W., Vautard, F., Askeland, P., Yu, J., Drzal, L.T., 2017: Incorporation of silicon dioxide nanoparticles at the carbon fiber-epoxy matrix interphase and its effect on composite mechanical properties. Polymer Composites 38(7): 1474-1482.

23. Riedlinger, D.A., Frazier, C.E., 2008: Morphological analysis of PF/pMDI hybrid wood adhesives. Journal of Adhesion Science and Technology 22(12): 1197-1208.

24. Roslan, R., Zakaria, S., Chia, C.H., Boehm, R., Laborie, M.P., 2014: Physico-mechanical properties of resol phenolic adhesives derived from liquefaction of oil palm empty fruit bunch fibres. Industrial Crops and Products 62: 119-124.

25. Schmidt, R.J., 2005: Industrial catalytic processes - phenol production. Applied Catalysis A: General 280(1): 89-103.

26. Shi, H., Liu, F., Yang, L., Han, E., 2008: Characterization of protective performance of epoxy reinforced with nanometer-sized $\mathrm{TiO}_{2}$ and $\mathrm{SiO}_{2}$. Progress in Organic Coatings 62(4): 359-368.

27. Sun, S., Li, C., Zhang, L., Du, H.L., Burnell-Gray, J.S., 2006: Effects of surface modification of fumed silica on interfacial structures and mechanical properties of poly (vinyl chloride) composites. European Polymer Journal 42(7): 1643-1652.

28. Viswanathan, T., Richardson, T., 1985: Thermosetting adhesive resins. Patent US4524164A.

29. Wang, J., Jiang, N., Jiang, H., 2010: Micro-structural evolution of phenol-formaldehyde resin modified by boron carbide at elevated temperatures. Materials Chemistry and Physics 120(1): 187-192.

30. Wang, M., Leitch, M., Xu, C.C., 2009: Synthesis of phenol-formaldehyde resol resins using organosolv pine lignins. European Polymer Journal 45(12): 3380-3388.

31. Wang, Z., Gu, Z., Hong, Y., Cheng, L., Li, Z., 2011: Bonding strength and water resistance of starch-based wood adhesive improved by silica nanoparticles. Carbohydrate Polymers 86(1): 72-76.

32. Yang, H., Zhang, Q. Guo, M., Wang, C., Du, R., Fu, Q., 2006: Study on the phase structures and toughening mechanism in $\mathrm{PP} / \mathrm{EPDM} / \mathrm{SiO}_{2}$ ternary composites. Polymer 47(6): 2106-2115.

33. Zhang, Y., Sigman, M.S., 2007: Palladium (II)-catalyzed enantioselective aerobic dialkoxylation of 2-propenyl phenols: A pronounced effect of copper additives on enantioselectivity. Journal of the American Chemical Society 129(11): 3076-3077. 
34. Zhang, Z., He, X., Wang, X., Rodrigues, A.M., Zhang, R., 2018: Reinforcement of the mechanical properties in nitrile rubber by adding graphene oxide/silicon dioxide hybrid nanoparticles. Journal of Applied Polymer Science 135(14): 46091.

35. Zhao, Y., Yan, N., Feng, M.W., 2013: Thermal degradation characteristics of phenolformaldehyde resins derived from beetle infested pine barks. Thermochimica Acta 555: 46-52.

36. Zhou, S., Wu, L., Sun, J., Shen, W., 2003: Effect of nanosilica on the properties of polyester-based polyurethane. Journal of Applied Polymer Science 88(1): 189-193.

\author{
GÜNAY ÖZBAY \\ Aksaray University \\ Department of Industrial Engineering \\ 68IOO AKSARAY \\ TURKEY \\ Erkan Sami KoKten* \\ Karabuk University \\ Department of Industrial Engineering \\ 78050 KaRABUK \\ TURKEY
}

*Corresponding author: erkansamikokten@karabuk.edu.tr

\author{
Ayhan Ozcifci \\ Aksaray University \\ Department of Industrial Engineering \\ 68ioo Aksaray \\ Turkey
}


